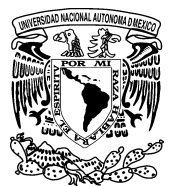

\title{
The implicit impact of cross-listing on stock prices: A market microstructure perspective - The case of Latin American markets
}

\author{
El impacto implícito de enlistar ADRs sobre los precios accionarios: una \\ perspectiva de microestructura - El caso de los mercados \\ latinoamericanos
}

\author{
Osmar Hazael Zavaleta Vázquez ${ }^{\mathrm{a}, *}$, Jaime González Maiz Jiménez ${ }^{\mathrm{b}}$ \\ a Tecnológico de Monterrey, EGADE Business School, Mexico \\ ${ }^{\mathrm{b}}$ Universidad de las Américas Puebla, Mexico
}

Received 30 January 2015; accepted 4 November 2015

Available online 12 February 2016

\begin{abstract}
The objective of this research is to evaluate the unobserved effect of cross-listing on stock prices of companies from Latin America. Particularly, we study the impact of the issuance of ADRs on volatility and efficiency in the local markets. We employ GARCH models to assess the impact on volatility, once the ADR has been issued, and ARMA models to evaluate the impact on efficiency, once the ADR is listed. Overall, we find that in $82 \%$ of the analyzed cases, at least one result shows improvement (i.e. lower volatility and/or more efficiency, once the corresponding ADR has been issued). Further, we find that once the electronic trading systems are implemented in emerging markets, there is an improvement in terms of the information environment, thus reducing the effects of cross-listing. This study contributes to the financial literature because it tests the impact of cross-listing on two specified market microstructure variables, namely volatility and efficiency, through a robust methodology.

All Rights Reserved ( 2015 Universidad Nacional Autónoma de México, Facultad de Contaduría y Administración. This is an open access item distributed under the Creative Commons CC License BY-NC-ND 4.0.
\end{abstract}

Keywords: Cross-listing; Information environment; Microstructure; Volatility and efficiency

\footnotetext{
* Corresponding author.

E-mail address: ozavaleta@itesm.mx (O.H. Zavaleta Vázquez).
}

Peer Review under the responsibility of Universidad Nacional Autónoma de México. 


\section{Resumen}

El objetivo de esta investigación es evaluar el efecto no aparente sobre los precios accionarios de Latinoamérica en el momento de emitir ADRs. En particular, se estudia el impacto sobre la volatilidad y la eficiencia en los mercados locales, empleando modelos de la familia GARCH, para medir el impacto sobre la volatilidad, y modelos ARMA, para evaluar el impacto sobre la eficiencia. En general, se encontró que en el $82 \%$ de los casos analizados, al menos un resultado muestra mejora (esto es, decremento en la volatilidad y/o mejora en la eficiencia). También se encontró que una vez que los sistemas electrónicos, para comprar y vender activos, son implementados en los mercados bajo estudio, hay una mejora en el ambiente de información, por lo que se reduce el efecto de emisión de los ADR. Finalmente, este estudio contribuye a la literatura financiera porque evalúa el impacto de la emisión de ADR sobre 2 variables específicas de la microestructura de los mercados financieros, volatilidad y eficiencia, mediante el uso de metodologías estadísticas consistentes.

Derechos Reservados @ 2015 Universidad Nacional Autónoma de México, Facultad de Contaduría y Administración. Este es un artículo de acceso abierto distribuido bajo los términos de la Licencia Creative Commons CC BY-NC-ND 4.0.

Palabras clave: Enlistar en el extranjero; Ambiente de información; Microestructura; Volatilidad y eficiencia

\section{Introduction}

There is a trade-off regarding listing a company abroad. On the one hand, Hayward (2002) mentions the two main advantages of listing shares abroad: (a) access to a greater capital market; and (b) an increase in the scope of brand awareness. On the other hand, the main drawbacks of listing abroad include: (c) large accounting and legal fees, and (d) extra disclosure requirements. Following the same line of thought, Lin (2011) highlights the various benefits associated with exchange listing, which potentially outweigh the compliance costs. Additionally, Waweru, Pokhariyal and Mwaura (2012) in a descriptive research design, find that the key reasons for cross-listing are: investor recognition, expansion of business, the boost in shares, and the desire to lower the cost of capital. Beyond these strategic issues, from the financial standpoint there has been a large body of research regarding how cross-listing impacts the stock price on different dimensions. In this paper, and from the market microstructure viewpoint, we are testing the impact of cross-listing on two microstructure variables: volatility and efficiency.

One of the objectives of market microstructure is to study how the trading mechanisms of financial markets influence variables that define its quality, namely transaction costs, volatility, liquidity and efficiency. Transaction costs are usually measured in terms of bid-ask spread; volatility measures the variation of returns over time and it is commonly measured in terms of the variance or standard deviation of stock returns; liquidity, which according to Bodie, Kane, and Marcus (2004), refers to the speed and ease with which an asset can be sold and still get a fair price; and efficiency, which is related to the idea of how close prices are in regards to reflecting all available information. In this work we will focus on two variables: volatility and efficiency. With the intention of gauging the impact on volatility, once the American Depositary Receipt (ADR hereafter) is issued, we employ Generalized Autoregressive Conditional Heteroskedasticity (GARCH hereafter) models in two senses: (a) conventional GARCH model and (b) the news impact curve model, which measures the asymmetry of volatility, implying that bad news should increase the volatility in stock returns more than good news do. Additionally, we estimate the proper Autoregressive Moving Average (ARMA hereafter) model to evaluate the impact on efficiency. 
The event of issuing an ADR, also known as cross-listing, is considered a quasi-natural experiment regarding the change in the information environment once companies issue ADRs. Thus, a number of research works has been focused to this observable fact. Broadly speaking, because companies coming from emerging markets are forced to disclose more financial information, it is natural to hypothesize that share prices of companies that cross-list will move closer to their fundamental or intrinsic value. Hence, the purpose of this research is to evaluate the implicit effect that ADR issuance has over two microstructure variables, volatility and efficiency, within the Latin American context. In order to accomplish this objective the paper is organized as follows: Section "Literature review" includes the Literature review. Section "Methodology and data description" describes the methodology to perform the empirical analysis on stock returns, as well as the description of used data. Section "Findings" presents the results from the empirical analysis. Finally, the general conclusions and future lines of research are presented in Section "Conclusions and future research".

\section{Literature review}

Because companies are forced to release more quality financial information once they cross-list, such releases are considered quasi-natural experiments in terms of the informationchanging environment. Thus, prior studies have hypothesized that once companies cross-list, either their share price is somehow better valued or they experience a change in other market-type measure.

In terms of market efficiency, Bhattacharya, Daouk, Jorgenson, and Kehr (2000), using a sample of Mexican corporate news announcements from July 1994 through June 1996, find that there is nothing unusual about returns, volatility of returns, volume of trade or bid-ask spreads in the event window. The authors show evidence that unrestricted insider trading has caused prices to fully incorporate the information.

On the other hand, Bekaert and Harvey (2002), considering a sample of 20 emerging markets (Argentina, Brazil, Chile, Colombia, Mexico and Venezuela included from Latin America), find that emerging market equity returns have higher serial correlation than developed market returns and that emerging markets returns are less likely to be impacted by company specific news announcements than developed market returns. The evidence suggests that insider trading occurs well before the release of information to the public which, in somewhat, indicates inefficiency in emerging markets.

Additionally, Eaton, Nofsinger, and Weaver (2007) study 20 countries - including Mexico and Chile representing Latin America - and find evidence that firms that cross-list experience a decrease in both disclosure risk and systematic risk. Fernandes and Ferreira (2008), throughout a cross-sectional study to compare the impact on information environment, after cross-listing, between developed and emerging market firms (included firms from Argentina, Brazil, Chile, Colombia, Mexico, Peru and Venezuela for the last group) find that cross-listing improves price informativeness for developed market firms, but cross-listing decreases price informativeness. Moreover, Nowland and Simon (2010), doing an analysis of 31 countries - Argentina, Brazil, Chile, Colombia, Mexico and Venezuela representing Latin America - show that cross-listing is associated with a shift away from less accurate forecasts toward more accurate forecasts. Finally, Salva and Fresard (2012) compare the value of firms that are cross-listed on the US exchanges to that of similar the US firms, and find a sizeable "cross-listing discount". They find that cross-listed firms are valued $14 \%$ lower than comparable the US firms. Their study of 38 countries includes Peru, Argentina, Brazil, Chile, Mexico and Venezuela. 
From the market microstructure standpoint, Domowitz, Glen, and Madhavan (1998) address the issue of cross-listing within the Mexican stock market, analyzing measures of domestic market quality including the precision of public information. The authors show a systematic change in volatility, liquidity, returns, and bid-ask spreads due to cross-listings being concentrated in share series open to foreign ownership prior to the listing event. Additionally, in a study of the Amman Stock Exchange, Al-Zoubi and Al-Zubi (2007) find evidence that stock returns follows an ARMA $(1,1)$ with significant serial correlation, implying stock market inefficiency. Hailing, Pagano, Randal, and Zechner (2008), using a sample of European countries, find that the fraction of trading that occurs in the US tends to be larger for companies from countries that are geographically close to the US and feature low financial development and poor insider protection. In contrast, Goto, Watanabe, and Xu (2009) in their study, that includes Mexico and Venezuela representing Latin America, find significant shifts in the time-series properties of stock returns for firms that experienced considerable changes in disclosure environments, such as those cross-listed in the US markets. More recently, Abdallah and Mohsen Saad (2011), whose study includes the stock markets from Argentina, Brazil, Chile and Mexico, conclude that the increase in trading volume due to cross-listing is a function of both reducing segmentation and signaling investor protection. In the same vein, Leyuan, Parhizgari, and Srivastava (2012) find a positive cross-listing and negative delisting effect on stock price. No significant changes in the market risk are found for either event. The authors find that foreign cross-listing and delisting are associated with increasing and decreasing long term trading volume respectively. Only one Mexican company was included in this study. Further, using data from Australian firms, Chang and Corbitt (2012), studying only the Australian Stock Exchange, do not reject the bonding hypothesis declaring that once companies cross-list, the insiders' returns are lowered.

\section{Methodology and data description}

\section{Methodology}

\section{GARCH models}

Volatility is one of the main variables within the market microstructure context. This variable is a measure of returns variation over time. We test whether there is an impact on this variable as a consequence of the issuance of ADRs. In order to evaluate the impact on returns volatility once the ADR is issued, we employ GARCH models.

The GARCH model was developed independently by Bollerslev (1986) and Taylor (1986). This model allows the conditional variance to be dependent upon previous own lags. In general, a GARCH $(1,1)$ model may be sufficient to capture volatility clustering data but, if necessary, a higher order model could be estimated. The general structure of a $\operatorname{GARCH}(p, q)$ model, adapted to the requirements of this paper, is as follows:

$$
\operatorname{Var}\left(\varepsilon_{t} \mid \Omega_{t-1}\right) \equiv \sigma_{t \mid \Omega_{t-1}}^{2}=\theta_{0}+\sum_{i=1}^{q} \theta_{i} \varepsilon_{t-i}^{2}+\sum_{j=1}^{p} \pi_{j} \sigma_{t-j}^{2}+D * A D R
$$

where $\theta_{0}>0$ and the $\operatorname{GARCH}(p, q)$ is covariance stationary only if $\sum_{i=1}^{q} \theta_{i}+\sum_{j=1}^{p} \pi_{j}<1 . \Omega_{t-1}$ indicates that the information set is available until period $t-1 ; D$ is the coefficient of the dummy variable $A D R$, and is relevant to evaluate the impact on the volatility due to the $A D R$ issuance. The 
variable $A D R$ takes the value of 0 before $A D R$ has been issued and takes the value of 1 once the $A D R$ was issued. The coefficient on the qualitative explanatory variable $D$ represents the volatility variation, in absolute terms. In order to evaluate the impact of the $A D R$ issuance, on the volatility of $\log$ returns $\left(\ln \left(P_{t} / P_{t-1}\right)\right)$, the following set of hypotheses will be tested:

$$
\begin{aligned}
& H_{0}: D \geq 0 \\
& H_{1}: D<0
\end{aligned}
$$

It is important to highlight that this is the structure used to model volatility cluster once the dynamic of the price variations was modeled with an ARMA structure.

\section{ARMA models}

Efficiency is another fundamental variable that is part of the market microstructure perspective. According to Fama (1991) a market is efficient when security prices fully reflect all available information, making it impossible to have an economic gain with the information of past returns only. In the context of Latin America, companies do not disclose enough quality financial information before they decide to issue an ADR, implying a certain degree of inefficiency and hence opening the possibility of having an economic gain with the information of past returns. Hence, once companies disclose more quality financial information, as a consequence of the cross-listing, an improvement within the market efficiency continuum is expected. In related studies regarding efficiency, using a variance-ratio methodology, Urrutia (1995) find that Latin American markets are weak-form efficient. Choundry (1997), investigates long-run relationships between Latin American markets and the United States, and find significant causality. On the other hand, within the Mexican Stock market, Domowitz et al. (1998), observe that Mexican shares that issue ADRs do experience a decline in the implicit Bid-Ask Spread, suggesting an improvement in terms of market efficiency. In addition, Bhattacharya et al. (2000), using a sample of Mexican corporate news announcements, find that there is nothing unusual about returns, volatility of returns, volume of trade or bid-ask spreads in the event window. The authors show evidence that unrestricted insider trading, which is a form of market inefficiency, has caused prices to fully incorporate the information. Furthermore, Bekaert and Harvey (2002) argue that emerging markets are relatively inefficient, since they have higher serial correlation than developed markets, and they suggest that insider trading occurs before the release of information to the public.

Specifically, we would expect, before domestic companies cross-list, the log returns of stock prices to take an ARMA $(p, q)$ structure:

$$
Y_{t}=\beta_{0}+\beta_{1} Y_{t-1}+\beta_{2} Y_{t-2}+\cdots+\beta_{p} Y_{t-p}+\alpha_{1} \varepsilon_{t-1}+\alpha_{2} \varepsilon_{t-2}+\cdots+\alpha_{q} \varepsilon_{t-q}+\varepsilon_{t}
$$

where $Y_{t}=\ln \left(P_{t} / P_{t-1}\right)$ is the $\log$ return of period $t$.

On the other hand, once companies issue the ADR, we would expect log returns of stock prices to take a random walk form which would imply, in somewhat, that the ADR issuance has induced efficiency. In other words, we would expect an AR(1) model with a unit root, as showed below:

$$
y_{t}=\beta_{0}+y_{t-1}+\varepsilon_{t}
$$

\section{The news impact curve}

According to Brooks (2008), the news impact curve plots the next-period volatility that would rise from various positive and negative values of $\varepsilon_{t-1}$. For the purposes of this research, we will test the news curve using both the Glosten, Jaganathan and Runkle (GJR) model and the exponential 
GARCH (EGARCH) model, proposed by Nelson (1991). In terms of the GJR GARCH model, the conditional variance is given by:

$$
\sigma_{t}^{2}=\phi_{0}+\phi_{1} \varepsilon_{t-1}^{2}+\varphi \sigma_{t-1}^{2}+\gamma \varepsilon_{t-1}^{2} I_{t-1}
$$

where:

$$
I_{t-1}= \begin{cases}1 & \text { if } \varepsilon_{t-1}<0 \\ 0 & \text { otherwise }\end{cases}
$$

For a leverage effect ${ }^{1} \gamma$ is greater than 0 . This model implies that bad news should increase the volatility in stock returns more than good news do.

On the other hand, the EGARCH model has the following form:

$$
\ln \left(\sigma_{t}^{2}\right)=\omega+\pi \ln \left(\sigma_{t-1}^{2}\right)+\theta \frac{\varepsilon_{t-1}}{\sqrt{\sigma_{t-1}^{2}}}+\lambda\left[\frac{\varepsilon_{t-1}}{\sigma_{t-1}^{2}}-\sqrt{\frac{2}{\pi}}\right]
$$

Given that companies are required to disclose more quality financial information, we expect that securities in the domestic market will have more visibility once the ADR was issued. Hence, in terms of the news impact curve models, we hypothesize that the leverage effect will decrease after companies cross-list.

In the case of the GJR GARCH model we expect that:

$$
H_{1}: \gamma_{b}>\gamma_{a}
$$

where $\gamma_{b}$ is the coefficient related to the leverage effect before cross-listing and $\gamma_{a}$ is the coefficient related to the leverage effect after cross-listing.

In the case of the E-GARCH model we expect that:

$$
H_{1}: \lambda_{b}>\lambda_{a}
$$

where $\lambda_{b}$ is the coefficient related to the leverage effect before cross-listing and $\lambda_{a}$ is the coefficient related to the leverage effect after cross-listing.

\section{Data description}

In order to estimate the models and perform the statistical tests we employed daily closing stock prices from every company, which were obtained from Bloomberg. We selected companies that issued ADRs from six countries, given their economic relevance within Latin America (Argentina, Brazil, Chile, Colombia, Mexico and Peru), which encompasses a total of 72 enterprises. Because of data availability, we could only retrieve relevant data from 34 companies, which belong to 18 industrial sectors (Tables 1 and 2 ).

Furthermore, it is important to notice that we could not gather the required data even for some well-known companies such as Grupo Televisa in Mexico, because the Group issued ADR in 1993, and there were not data available from that date. In order to execute the tests we considered a window of time of 80 days before the event of cross-listing and 80 days after the event of cross-listing, leaving 20 days before and 20 days after cross-listing without analysis in order to

\footnotetext{
${ }^{1}$ Enders (2010) defines the leverage effect as the tendency for volatility to decline when returns rise and to rise when returns fall.
} 
Table 1

ADRs issue dates and available data.

\begin{tabular}{|c|c|c|}
\hline Country/company & ADRs issue date & Available data \\
\hline \multicolumn{3}{|l|}{ Argentina } \\
\hline Alto Palermo & $11 / 15 / 2000$ & Yes \\
\hline Banco Macro & $03 / 23 / 2006$ & Yes \\
\hline Patagonia & $07 / 19 / 2007$ & No \\
\hline Cresud & 03/18/1997 & Yes \\
\hline Emp Distribuidora & $04 / 26 / 2007$ & No \\
\hline BBVA Banco & $11 / 24 / 1993$ & No \\
\hline Grupo Galicia & $07 / 24 / 2000$ & No \\
\hline IRSA & $12 / 20 / 1994$ & Yes \\
\hline Nortel & 2/27/1998 & No \\
\hline Pampa & $10 / 0 / 2009$ & Yes \\
\hline Petrobras Argentina & 09/30/2009 & Yes \\
\hline Telecom & $01 / 12 / 1994$ & Yes \\
\hline Transport Ga & 11/17/1994 & No \\
\hline YPF & $06 / 29 / 1993$ & No \\
\hline \multicolumn{3}{|l|}{ Brazil } \\
\hline Agrenco & $10 / 24 / 2007$ & No \\
\hline Ambev & 08/01/1996 & Yes \\
\hline Banco Santander & $10 / 06 / 2009$ & No \\
\hline Bradesco & 06/13/1997 & Yes \\
\hline Braskem & $05 / 15 / 1995$ & Yes \\
\hline $\mathrm{BRF}$ & 01/07/1997 & No \\
\hline Cemig & $04 / 17 / 1995$ & Yes \\
\hline Copel & 07/30/1997 & No \\
\hline CPFL Energia & $09 / 28 / 2004$ & No \\
\hline Eletrobras & $05 / 15 / 1995$ & Yes \\
\hline \multicolumn{3}{|l|}{ Brazil } \\
\hline Embraer & $07 / 20 / 2000$ & Yes \\
\hline Fibria Celulosa & 07/06/1995 & Yes \\
\hline Gafisa & 03/16/2007 & Yes \\
\hline Gerdau & 02/20/1998 & Yes \\
\hline Gol & $06 / 26 / 2004$ & No \\
\hline Itau & $07 / 02 / 2001$ & Yes \\
\hline Net Servi & 11/01/1996 & No \\
\hline OI SA & 04/02/1997 & Yes \\
\hline PAO Acucar & 10/13/1995 & No \\
\hline Petrobras & 11/13/1996 & Yes \\
\hline Sabesp & $05 / 10 / 2002$ & Yes \\
\hline SID Nacional & $05 / 15 / 1995$ & Yes \\
\hline Telefonica & 11/16/1998 & No \\
\hline TIM Particip & 11/16/1998 & No \\
\hline Ultrapar & 10/06/1999 & No \\
\hline Vale & 05/15/1995 & Yes \\
\hline \multicolumn{3}{|l|}{ Mexico } \\
\hline Amércia Móvil & $02 / 07 / 2001$ & No \\
\hline Cemex & 09/15/1999 & Yes \\
\hline Coca Cola & $09 / 14 / 1993$ & No \\
\hline Desarrolladora & $06 / 28 / 2004$ & No \\
\hline ICA & 04/09/1992 & No \\
\hline Femsa & 05/11/1998 & Yes \\
\hline
\end{tabular}


Table 1 (Continued)

\begin{tabular}{lll}
\hline Country/company & ADRs issue date & Available data \\
\hline Gruma & $44 / 06 / 1998$ & Yes \\
Grupo Aeropuertario & $09 / 27 / 2000$ & No \\
Mexico & & \\
Santander & $09 / 25 / 2012$ & No \\
Grupo Simec & $07 / 01 / 1993$ & No \\
Grupo Televisa & $12 / 14 / 1993$ & No \\
Grupo TMM & $06 / 10 / 1992$ & Yes \\
Chile & & \\
Banco Chile & $01 / 02 / 2002$ & Yes \\
Banco Santander & $01 / 13 / 1997$ & No \\
Cencosud & $11 / 17 / 2005$ & Yes \\
Cervezas & $09 / 24 / 1992$ & No \\
Embotelladora Andina & $07 / 06 / 1994$ & No \\
Endesa & $07 / 27 / 1994$ & Yes \\
Enersis & $10 / 20 / 1993$ & No \\
Latam & $11 / 07 / 1997$ & Yes \\
Provida & $11 / 16 / 1994$ & No \\
Quimica & $06 / 13 / 1994$ & No \\
Vino y Concha & $10 / 14 / 1994$ & No \\
Colombia & & Yes \\
Bancolombia & $07 / 15 / 1996$ & Yes \\
Ecopetrol & $09 / 18 / 2008$ & \\
Peru & & \\
Buenaventura & & \\
Cementos Pacasma & & \\
\hline & & \\
& & \\
\hline
\end{tabular}

Table 2

Economic sectors of the analyzed companies.

\begin{tabular}{|c|c|c|c|c|}
\hline Sector & Company/country & Company/country & Company/country & Company/country \\
\hline Real Estate & Apsa (Arg) & Ipsa (Arg) & Gafisa (Bra) & \\
\hline Banking & Banco Macro (Arg) & Itau and Bradesco (Bra) & Banco Chile & CorpBanca (Chile) \\
\hline Utilities & Pampa (Arg) & Cemig (Bra) & Eletrobras (Bra) & Endesa (Chile) \\
\hline Telecommunications & Telecom (Arg) & Obir (Bra) & & \\
\hline Oil and Gas & Petrobras (Arg) & Petrobras (Bra) & Eco-Petrol (Col) & \\
\hline Food & Ambev (Bra) & Gruma (Mex) & & \\
\hline Petrochemicals & Braskem (Bra) & & & \\
\hline Aircraft & Embraer (Bra) & & & \\
\hline Paper & Fibria (Bra) & & & \\
\hline Steel & Gerdau (Bra) & Sid Nacional (Bra) & & \\
\hline Water & Sabesp (Bra) & & & \\
\hline Mining & Vale (Bra) & Buenaventura (Peru) & & \\
\hline Construction & Cemex (Mex) & Cementos Pacasma (Peru) & & \\
\hline Bottler & Femsa (Mex) & & & \\
\hline Logistics & Grupo TMM (Mex) & & & \\
\hline Retailing & Cencosud (Chile) & & & \\
\hline Airlines & Latam (Chile) & & & \\
\hline Agriculture & Cresud (Arg) & & & \\
\hline
\end{tabular}


avoid noise effects. On the other hand, to be consistent, the window of 80 days was chosen on the basis that it was the maximum we could retrieve for some companies.

So, we have to recognize that the results obtained from this research are not totally conclusive, given that analyses were performed on less than half of the companies that have issued an ADR in Latin America, but under the robustness of the statistical methodology with which each company was analyzed, we are confident that the findings are enough developers to understand the effect of this financial event on the volatility and efficiency of each company.

\section{Findings}

Putting in perspective the raw results, in Fig. 1, we depict the graphs that show a clear decline in volatility after cross-listing (Petrobras Argentina, Braskem, Cemig, Eletrobras, Gerdau, Sid Nacional, Ambev, Fibria Celulosa, Vale, Latam and Ecopetrol), whereas the remaining companies show no apparent effect. As it was described in Methodology section, one of the purposes of this paper is to test whether there is an impact on the volatility as a consequence of the issuance of ADRs. In terms of what has been exposed previously, it is expected that volatility decrease once an ADR has been issued.
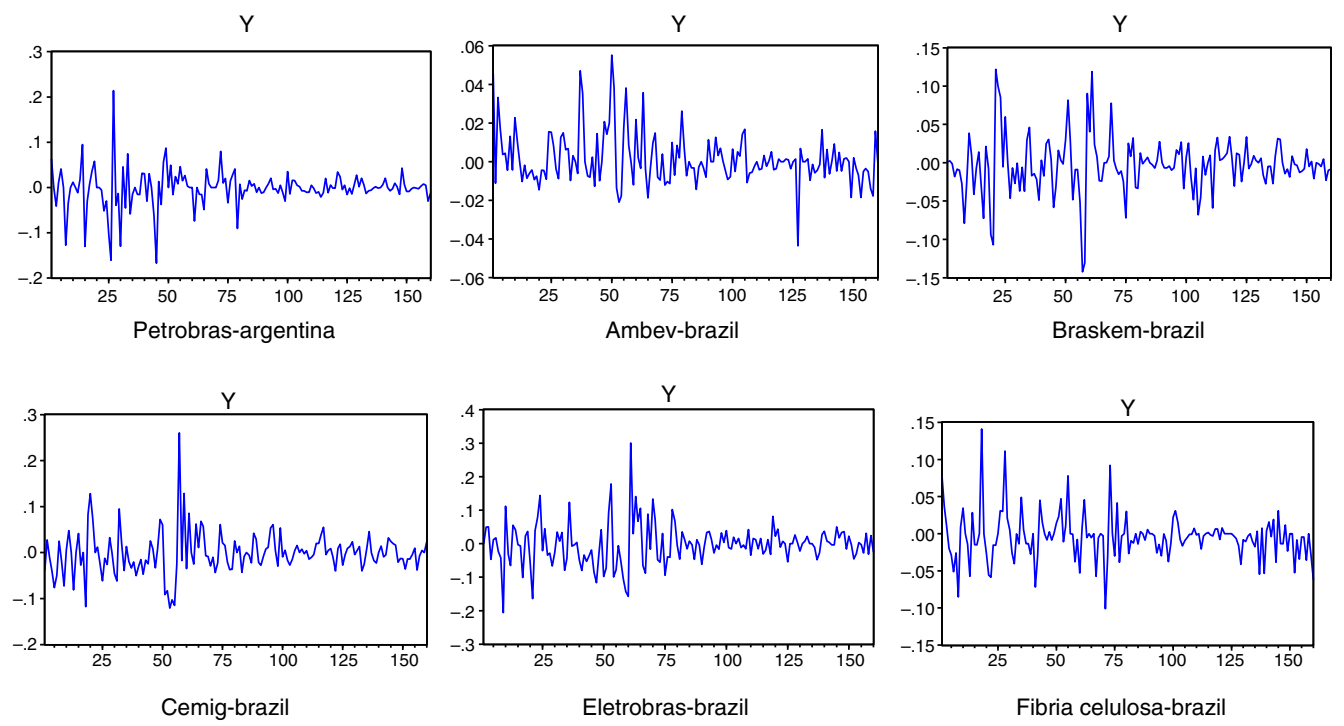

Y

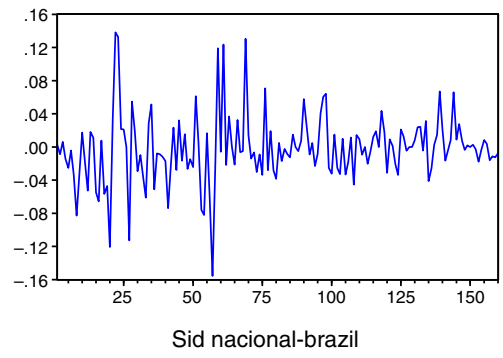

Y

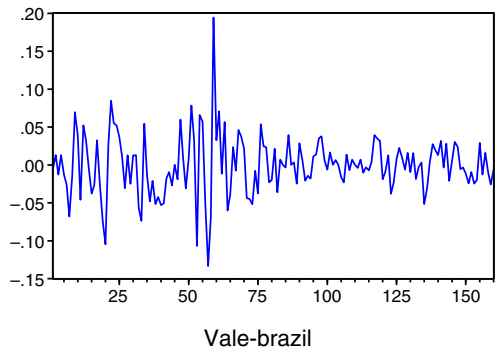

Fig. 1. Volatilities of some analyzed companies. 
Table 3

General results.

\begin{tabular}{|c|c|c|c|c|}
\hline Country/company & $\begin{array}{l}\text { GARCH - effect } \\
\text { as expected }\end{array}$ & $\begin{array}{l}\text { Market efficiency test - } \\
\text { effect as expected }\end{array}$ & $\begin{array}{l}\text { News impact curve - } \\
\text { effect as expected }\end{array}$ & $\begin{array}{l}\% \text { of results as } \\
\text { expected }\end{array}$ \\
\hline \multicolumn{5}{|l|}{ Argentina } \\
\hline Alto Palermo & No & No & No & 0 \\
\hline Banco Macro & No & Yes & No & 33 \\
\hline Cresud & Yes & No & Yes $^{\mathrm{a}}$ & 67 \\
\hline IRS & No & No & Yes & 33 \\
\hline Pampa & Yes & Yes & No & 67 \\
\hline Telecom & No & No & No & 0 \\
\hline Petrobras Arg & Yes & Yes & Yes $^{\mathrm{a}}$ & 100 \\
\hline Consistency per country & $43 \%$ & $43 \%$ & $43 \%$ & 43 \\
\hline \multicolumn{5}{|l|}{ Brazil } \\
\hline Ambev & Yes & No & No & 33 \\
\hline Bradesco & No & Yes & No & 33 \\
\hline Braskem & Yes & No & Yes & 67 \\
\hline Cemig & Yes & Yes & Yes & 100 \\
\hline Eletrobras & Yes & No & Yes $^{\mathrm{a}}$ & 67 \\
\hline Embraer & Yes & Yes & Yes $^{\mathrm{b}}$ & 100 \\
\hline Fibria Celulosa & Yes & Yes & Yes $^{\mathrm{b}}$ & 100 \\
\hline Gafisa & No & No & No & 0 \\
\hline Gerdau & Yes & No & Yes $^{\mathrm{b}}$ & 67 \\
\hline Itau & Yes & No & No & 33 \\
\hline Oibr & Yes & No & Yes $^{\mathrm{b}}$ & 67 \\
\hline Petrobras & No & Yes & Yes $^{\mathrm{b}}$ & 67 \\
\hline Sabesp & No & No & Yes & 33 \\
\hline Sid Nacional & Yes & Yes & Yes & 100 \\
\hline Vale & Yes & No & No & 33 \\
\hline Consistency per country & $75 \%$ & $40 \%$ & $67 \%$ & 60 \\
\hline \multicolumn{5}{|l|}{ Mexico } \\
\hline Cemex & No & No & No & 0 \\
\hline Femsa & No & No & No & 0 \\
\hline Gruma & Yes & Yes & No & 67 \\
\hline Grupo TMM & Yes & No & No & 33 \\
\hline Consistency per country & $50 \%$ & $25 \%$ & $0 \%$ & 25 \\
\hline \multicolumn{5}{|l|}{ Chile } \\
\hline Banco Chile & Yes & No & Yes & 67 \\
\hline Cencosud & No & No & No & 0 \\
\hline Corpbanca & No & No & Yes $^{\mathrm{a}}$ & 33 \\
\hline Endesa & No & No & Yes $^{\mathrm{a}}$ & 33 \\
\hline Latam & Yes & No & No & 33 \\
\hline Consistency per country & $40 \%$ & $0 \%$ & $60 \%$ & 40 \\
\hline \multicolumn{5}{|l|}{ Colombia } \\
\hline Ecopetrol & Yes & No & Yes $^{\mathrm{a}}$ & 67 \\
\hline \multicolumn{5}{|l|}{ Peru } \\
\hline Buenaventura & No & No & Yes & 33 \\
\hline Cementos Pacasma & Yes & Yes & Yes & 100 \\
\hline Consistency per country & $50 \%$ & $50 \%$ & $100 \%$ & 67 \\
\hline Overall consistency & $59 \%$ & $32 \%$ & $56 \%$ & 49 \\
\hline
\end{tabular}

The volatility was tested via the two models: GARCH and EGARCH, thus in some cases only one of the two got the expected result.

a The results were as expected in the GJR GARCH model only: $b>a$, where $b$ is the coefficient related to the leverage effect before cross-listing and $a$ is the coefficient related to the leverage effect after cross-listing.

$\mathrm{b}$ The results were as expected in the EGARCH model only: $\mathrm{b}>\mathrm{a}$ where $\mathrm{b}$ is the coefficient related to the leverage effect before cross-listing and $\mathrm{a}$ is the coefficient related to the leverage effect after cross-listing. 
Table 4

General results, discerning results regarding the introduction of the electronic system.

\begin{tabular}{|c|c|c|c|c|}
\hline Country/company & $\begin{array}{l}\text { GARCH - effect } \\
\text { as expected }\end{array}$ & $\begin{array}{l}\text { Market efficiency } \\
\text { test - effect as } \\
\text { expected }\end{array}$ & $\begin{array}{l}\text { News impact } \\
\text { curve - effect as } \\
\text { expected }\end{array}$ & $\begin{array}{l}\% \text { of results as } \\
\text { expected }\end{array}$ \\
\hline
\end{tabular}

\section{Argentina}

Issue ADRs before the system

Banco Macro the system

Pampa Yes

Petrobras Arg Yes

Consistency $67 \%$

Issue ADRs after the system

$\begin{array}{ll}\text { Alto Palermo } & \text { No } \\ \text { Cresud } & \text { Yes } \\ \text { IRS } & \text { No } \\ \text { Telecom } & \text { No } \\ \text { Consistency } & 25 \% \\ \text { Overall consistency } & 43 \%\end{array}$

\section{Brazil}

Issue ADRs before the system

\begin{tabular}{|c|}
\hline Ambev \\
\hline Bradesco \\
\hline Braskem \\
\hline Cemig \\
\hline Eletrobras \\
\hline Embraer \\
\hline Fibria Celulosa \\
\hline Gerdau \\
\hline Petrobras \\
\hline Sid Nacional \\
\hline Vale \\
\hline Consistency \\
\hline
\end{tabular}

Issue ADRs after the system

Gafisa

Oibr

No

Itau Yes

Yes

Sabesp No

Consistency $\quad 50 \%$

Overall consistency $\quad 73 \%$

Mexico

Issue ADRs before the system

Cemex

No

Femsa

No

Gruma

Yes

Grupo TMM

Yes

Consistency

$50 \%$

\section{Chile}

Issue ADRs after the system

Banco Chile

Cencosud

Corpbanca

Endesa

Yes
No
No
No

Yes

No

No
Yes

Yes

Yes

$100 \%$

No

No

No

No

$0 \%$

$43 \%$

No

Yes

No

Yes

No

Yes

Yes

No

Yes

Yes

No

$55 \%$

No

No

No

No

$0 \%$

$40 \%$

No

No

Yes

No

$25 \%$
No

No

Yes

$33 \%$

No

Yes $^{\mathrm{a}}$

Yes

No

$50 \%$

$43 \%$

33

67

100

67

67

67

33

0

25

43

No 33

No 33

Yes $\quad 67$

Yes 100

Yes $^{\mathrm{a}} \quad 67$

Yes $^{\text {b }} \quad 100$

Yes $^{\text {b }} \quad 100$

Yes $^{\mathrm{b}} \quad 67$

Yes $^{\text {b }} \quad 67$

Yes 100

No 33

$73 \% \quad 70$

No 0

Yes $^{\mathrm{b}} \quad 67$

No 33

Yes 33

$50 \% \quad 33$

$67 \% \quad 60$

No 0

No 0

No 67

No $\quad 33$

$0 \% \quad 25$
No

No

No

No
Yes

No

Yes $^{\mathrm{a}}$

Yes $^{\mathrm{a}}$
67

33

33 
Table 4 (Continued)

\begin{tabular}{|c|c|c|c|c|}
\hline Country/company & $\begin{array}{l}\text { GARCH - effect } \\
\text { as expected }\end{array}$ & $\begin{array}{l}\text { Market efficiency } \\
\text { test - effect as } \\
\text { expected }\end{array}$ & $\begin{array}{l}\text { News impact } \\
\text { curve - effect as } \\
\text { expected }\end{array}$ & $\begin{array}{l}\% \text { of results as } \\
\text { expected }\end{array}$ \\
\hline Latam & Yes & No & No & 33 \\
\hline Consistency & $40 \%$ & $0 \%$ & $60 \%$ & 40 \\
\hline \multicolumn{5}{|l|}{ Colombia } \\
\hline \multicolumn{5}{|l|}{ Issue ADRs after the system } \\
\hline Ecopetrol & Yes & No & Yes $^{\mathrm{a}}$ & 67 \\
\hline \multicolumn{5}{|l|}{ Peru } \\
\hline \multicolumn{5}{|l|}{ Issue ADRs after the system } \\
\hline Buenaventura & No & No & Yes & 33 \\
\hline Cementos Pacasma & Yes & Yes & Yes & 100 \\
\hline Overall consistency before the system & $72 \%$ & $55 \%$ & $50 \%$ & 54 \\
\hline Overall consistency after the system & $44 \%$ & $6 \%$ & $63 \%$ & 38 \\
\hline Overall consistency & $59 \%$ & $32 \%$ & $56 \%$ & 49 \\
\hline
\end{tabular}

a The results were as expected in the GARCH model only.

b The results were as expected in the EGARCH model only.

To better grasp the results of this research, given the large amount of estimations, we show the general results in some tables. In Table 3, we present the broad results and it can be observed that, in the overall, $49 \%$ of the results were as expected. In particular, 59\% of the tested companies show a decrease in volatility (GARCH model), 32\% show improvement in terms of efficiency (ARMA models), and 56\% of companies show a decrease in volatility when news impact model is used. In terms of countries, Brazil, with the biggest sample, shows an overall consistency of $60 \%$. However, Mexico is the least consistent with only $25 \%$ of expected results. In particular, $46 \%$ of tested companies show a decrease in volatility (GARCH model), $8 \%$ show an improvement in terms of efficiency (ARMA models), and 54\% show a decrease in volatility when facing bad news (news impact curve).

In the search for the determinants of differences of outputs across countries, we divide the results before and after the introduction of electronic trading systems in each country ${ }^{2}$ and, interestingly, we find that, in general, before the introduction of electronic trading systems, there was consistency of $54 \%$ of expected results for the whole region, whereas after the introduction of electronic systems, there was a consistency of $38 \%$ of expected results. These results suggest that the introduction of electronic systems produces an implicit improvement - in terms of the information environment. Thus, information environment efficiency is improved only slightly due to ADR effects after the mentioned systems are implemented (Table 4). On the other hand, in terms of sectors, and considering only the companies that issued ADRs before the introduction of electronic trading systems, we find that the most consistent sectors are aircraft and paper with $100 \%$, whereas construction and bottling has a $0 \%$ consistency. In sum, all tables show the

\footnotetext{
${ }^{2}$ Implementation date of the electronic trading system, in the stock market, for each country included in this research: Argentina: March, 1999. Source: http://www.bcba.sba.com.ar.

Brazil: June 1997. Source: http://www.bmfbovespa.com.br/.

Chile: November, 1989. Source: http://www.bolchile.cl.

Colombia: October, 2001. Source: https://www.bvc.com.co.

Mexico: January, 1999. Source: http://www.bmv.com.mx.

Peru: October, 1997. Source: http://www.bvl.com.pe.
} 
general results regarding the proposed models to test the event of cross-listing through the use of two market microstructure variables: volatility and efficiency, where in $82 \%$ of the cases, at least one test resulted as expected. It would be interesting to study the reasons why differences exist across nations and industrial sectors. Moreover, variables such as analyst' coverage and/or valuation could be analyzed in order to further the scope of this study.

Even though the results obtained from this research are not totally conclusive, given that the analyses were performed on less than a half of the companies that have issued an ADR in Latin America, we have found robust evidence that shows an improvement in the efficiency and volatility in most of the analyzed companies. These results suggest, in general terms, that the information disclosure required in the issuance of an ADR contributes to improve the quality of the microstructure variables. Moreover, these results could suggest that, in somewhat, the stock trading in some Latin American markets is not totally efficient, which could discourage investors to fund productive projects through the stock markets.

\section{Conclusions and future research}

It is important to highlight the role that the financial markets have in the development and growth of a country's productive base. Due to the needs of growth and expansion of businesses, financial markets (both capital and debt) represent an important source of financing to promote and foster productive projects that generate wealth and welfare for the society as a whole. Because of this, it is really important that investors feel confident about the quality of a financial market. Efficiency and volatility, among others, are two variables that reflect the quality of a financial market.

This study measures the impact of the issuance of ADRs of Latin American companies over two microstructure variables, volatility and efficiency. For volatility, we estimate two kinds of GARCH models: the traditional GARCH model, which models variation on volatility over time, and the news impact curve, which analyzes the asymmetry of volatility. For efficiency, we estimate ARMA family models in order to determine the predictability of log returns. In related studies, Domowitz et al. (1998) address the issue of cross-listing within the Mexican stock market context, and find a systematic change in volatility, liquidity, returns, and bid-ask spreads result after the cross-listing event. Leyuan et al. (2012) note that foreign cross-listing and delisting are associated with increasing and decreasing long term trading volume, respectively. Chang and Corbitt (2012) do not reject the bonding hypothesis declaring that once companies cross-list, the insiders' returns are lowered.

In regards to the findings, in $82 \%$ of the cases, at least one result is as expected. Overall, $49 \%$ of the results are as expected, with $59 \%$ of companies showing a decrease in volatility, $32 \%$ showing improvements in efficiency, and 56\% showing a decrease in volatility when facing bad news. Brazil, with the biggest sample, shows an overall consistency of $60 \%$, whereas Mexico is the least consistent with $25 \%$. However, breaking down the findings by sector, the oil and gas exploration sector has a consistency of $78 \%$, and real estate sector has consistency of only $25 \%$. We give further detail regarding efficiency tests, dividing the results into three parts: effect as expected, effect opposite of expected, and no effect, observing that when results are not as expected, the remaining results are not the opposite of what was expected, but rather has no effect. Additionally, dividing the findings before and after the introduction of electronic trading systems in each country, we find that before the introduction of electronic systems, in general, there is a consistency of $54 \%$ of expected results in the whole region, whereas after the introduction of electronic systems, there is a consistency of only $38 \%$ of expected results, suggesting that with the introduction of 
electronic systems, there is an implicit improvement in terms of the information environment, which accounts for the reduction of the information environment efficiency due to ADR effects. Further research should examine the reasons for differences across nations and industrial sectors, in addition to the proposed market microstructure variables. For example, analysts' coverage and/or valuation could be added up to such research.

It can be said that this study empirically tests the unobserved effect of a changing information environment event such as cross-listing over two Microstructure variables: volatility and efficiency within the Latin American context, finding novel results throughout the use of innovative models. Nevertheless, further investigation from the market microstructure standpoint on the cross-listing event within a proposed region should be conducted. Furthermore, the proposed measures in this work can be tested with regards to another changing-information environment event, such as the SOX act.

Despite the results obtained from this research are not totally conclusive, given that the analyses were performed on less than a half of the companies that have issued an ADR in Latin America, we have found robust evidence that shows an improvement in the efficiency and volatility in most of the analyzed companies suggesting, in general terms, that the information disclosure required in the issuance of an ADR contributes to improve the behavior of these variables. In addition, these results could suggest that, in somewhat, the stock trading in some Latin American markets is not totally efficient, which could discourage investors to fund productive projects through the stock markets. So, this paper provides some evidence to recognize that the financial markets analyzed in this work should be improved regarding information disclosure, which is a fundamental aspect to foster investors' confidence in order to finance productive projects that foster country's economic growth. This is a pending task for the government authorities.

\section{References}

Abdallah, A., \& Mohsen Saad, A. (2011). The effect of cross-listing on trading volume: Reducing segmentation versus signaling investor protection. Journal of Financial Research, 34, 589-616.

Al-Zoubi, H., \& Al-Zubi, B. (2007). Market efficiency, time-varying volatility and the asymmetric effect in Amman stock exchange. Managerial Finance, 33, 490-499.

Bekaert, G., \& Harvey, C. (2002). Research in emerging markets finance: Looking to the future. Emerging Markets Research, 3, 429-448.

Bhattacharya, U., Daouk, H., Jorgenson, B., \& Kehr, C. H. (2000). When an event is not an event: The curious case of an emerging market. Journal of Financial Economics, 55, 69-101.

Bodie, Kane, \& Marcus. (2004). Investments. New York, NY: McGraw Hill/Irwin.

Bollerslev, T. (1986). Generalised autoregressive conditional heteroskedasticity. Journal of Econometrics, 31, $307-327$.

Brooks, C. (2008). Introductory econometrics for finance. Cambridge: Cambridge University Press.

Chang, M., \& Corbitt, R. (2012). The effect of cross-listing on insider trading returns. Accounting \& Finance, 52, 723-741.

Choundry, T. (1997). Stochastic trends in stock prices: Evidence from Latin American markets. Journal of Macroeconomics, 19, 285-304.

Domowitz, I., Glen, J., \& Madhavan, A. (1998). International cross-listing and order flow migration: Evidence from an emerging market. Journal of Finance, 53, 2001-2027.

Eaton, T., Nofsinger, J., \& Weaver, D. (2007). Disclosure and the cost of equity in international cross-listing. Review of Quantitative Finance and Accounting, 29, 1-23.

Enders, W. (2010). Applied econometric time series. New Jersey: John Wiley \& Sons.

Fama, E. (1991). Efficient capital markets II. Journal of Finance, 46, 1575-1617.

Fernandes, N., \& Ferreira, M. (2008). Does international cross-listing improve the information environment. Journal of Financial Economics, 88, 216-244.

Goto, S., Watanabe, M., \& Xu, Y. (2009). Strategic disclosure and stock returns: Theory and evidence from US cross-listing. The Review of Financial Studies, 22, 1585-1620. 
Hailing, M., Pagano, M., Randl, O., \& Zechner, J. (2008). Where is the market? Evidence from cross-listings in the US. The Review of Financial Studies, 21, 725-761.

Hayward, C. (2002). Dual listing in the U.S. adds to credibility. Financial Management, june, 4

Leyuan, Y., Parhizgari, A., \& Srivastava, S. (2012). Cross-listing and subsequent delisting in foreign markets. Journal of Empirical Finance, 19, 200-216.

Lin, J. (2011). The Effect of US GAAP Compliance on Non-US Firms' Cross-Listing Decisions and Choices. International Journal of Economics \& Finance, 3(6), 42-56.

Nelson, D. B. (1991). Conditional heteroskedasticity in asset returns: A new approach. Econometrica, 59, 347-370.

Nowland, J., \& Simon, A. (2010). The effect of a change in analyst composition on analyst forecast accuracy: Evidence from US cross-listings. Journal of International Accounting Research, 9, 23-38.

Salva, C., \& Fresard, L. (2012). To what extent do cross-listing firms integrate into the US environment. SSRN working paper series.

Taylor, S. J. (1986). Forecasting the volatility of currency exchange rates. International Journal of Forecasting, 3, 159-170.

Urrutia, J. (1995). Tests of random walk and market efficiency for Latin American emerging equity markets. Journal of Financial Research, 18, 299-309.

Waweru, K. M., Pokhariyal, G., \& Mwaura, M. (2012). The Key Reasons for Cross-Listing in East African Stock Exchanges by Firms listed in the Nairobi Securities Exchange. International Journal of Business \& Management, 7(16), 118-124. 